\title{
Clinical Reasoning: Progressive proximal weakness in a 56-year-old man with bone pain
}

Tara Torabi, MSc, Anita Huttner, MD, Richard J. Nowak, MD, MS, and Bhaskar Roy, MD

Neurology ${ }^{\circledR}$ 2019;93:939-944. doi:10.1212/WNL.0000000000008535
Correspondence

Dr. Roy

bhaskar.roy@yale.edu

\section{Section 1}

A 56-year-old man was admitted to an outside hospital for worsening weakness and fatigue in the setting of upper respiratory infection. He had noticed gradually progressive weakness over the last year. Initially, he experienced difficulty lifting both arms above his shoulder; this progressed to difficulty walking, getting up from a low seated position, and climbing stairs for the last 6 months. In addition, he endorsed worsening bone and joint pain that had started approximately 1.5 years ago.

The patient was a current smoker and had been smoking $1 / 2$ pack of cigarettes a day since the age of 18 . His medical history was notable for chronic obstructive pulmonary disease. He denied any recent vaccinations. There was no known family history of neurologic disease. His father died from a heart attack at age 56 and his mother from early-onset Alzheimer disease. Birth history was unrevealing, and he achieved motor milestones in time.

Given the patient's worsening weakness in the setting of acute respiratory illness, chronic inflammatory demyelinating polyradiculoneuropathy (CIDP) with an acute flare was initially suspected. However, there were no sensory symptoms and reflexes were intact, thus MRI of spine with contrast was performed before considering lumbar puncture. MRI spine was unremarkable except for sclerotic lesions in C4 and C7 vertebra. MRI brain was also normal. Bone scan performed to investigate these vertebral lesions revealed several foci of increased activity in the cervical, thoracic, and lumbar spine, along with an inhomogeneous sclerotic and lytic lesion of the left radius (figure, D).

Laboratory workup showed mild elevation of alkaline phosphatase (135 IU/L, normal 40-115 $\mathrm{U} / \mathrm{L})$. Creatinine kinase (CK) $(121 \mathrm{U} / \mathrm{L}$, normal 44-196 U/L), aldolase $(4.8 \mathrm{U} / \mathrm{L}$, normal 1.0-7.5 U/L), and serum calcium $(9.7 \mathrm{mg} / \mathrm{dL}$, normal $8.6-10.3 \mathrm{mg} / \mathrm{dL})$ were normal. Inflammatory and rheumatologic markers were negative and there was no evidence of an endocrinopathy. Serum kappa and lambda light chains were mildly elevated but serum protein electrophoresis and immunofixation were normal.

Considering multiple bone lesions, and the patient's longstanding smoking history, a metastatic disorder was suspected, but a CT scan of the chest, abdomen, and pelvis did not reveal evidence of an occult malignancy. Interestingly, CT chest showed fatty atrophy of the chest wall muscles (figure, C). PET scan showed only increased uptake in the vertebral lesions. No unifying diagnosis could be made, and he was referred to our neuromuscular clinic, where he was seen about 4 months later. In the interim, his weakness continued to progress, and he started to fall frequently.

\section{Questions for consideration:}

1. Can there be a connection between the patient's bone lesions and his weakness?

2. What is your differential and how would you proceed? 
Figure Key clinical features and diagnostic findings

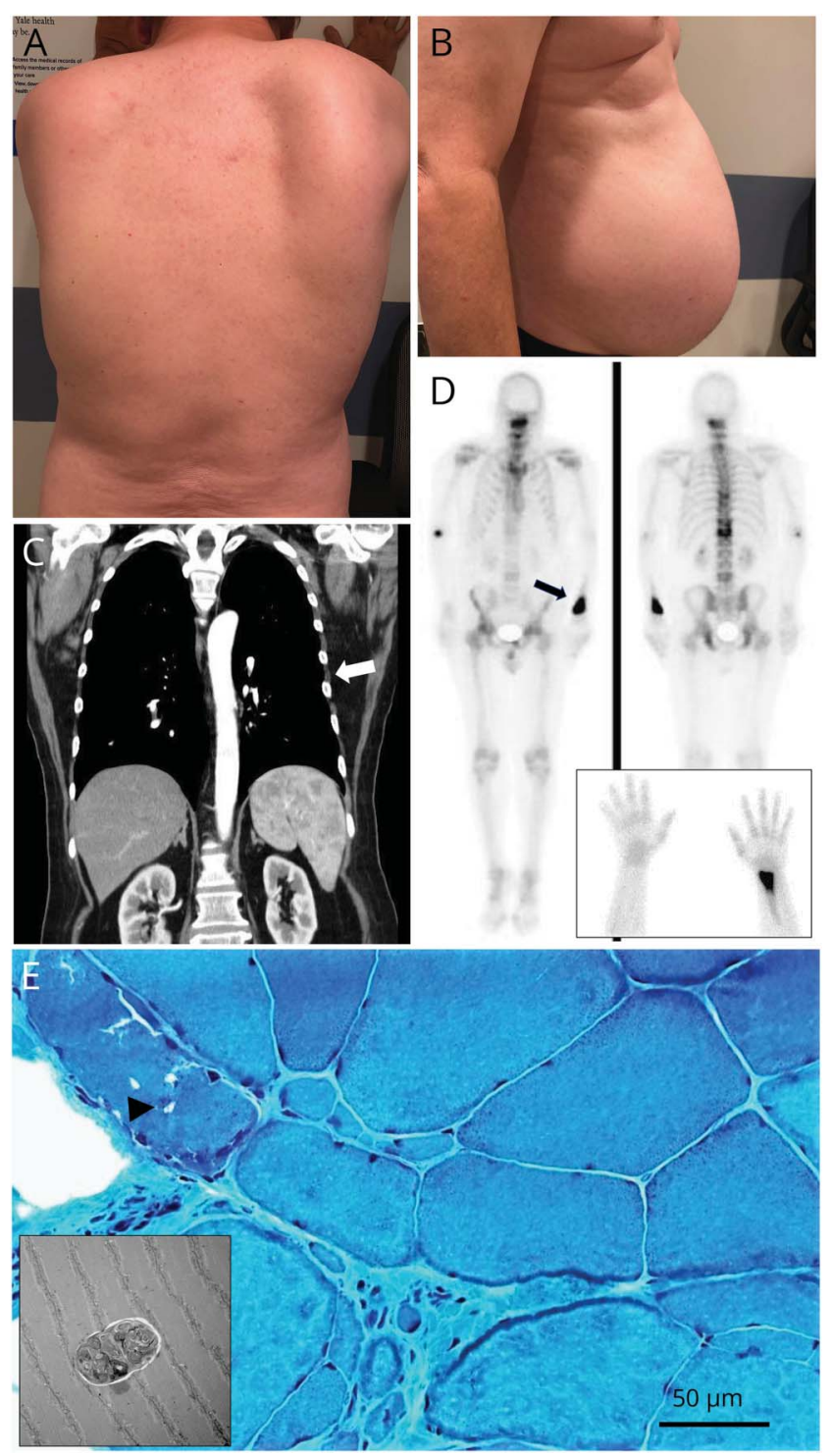

(A) Right scapular winging, (B) protruding abdomen, (C) muscle atrophy of chest wall muscles (white block arrow) on CT chest, (D) bone scan showing inhomogeneous sclerotic and lytic lesion involving the distal left radius (black block arrow, and the inset figure), and several foci of increased activity in the cervical and thoracic spine, (E) Gomori trichrome stain showing fiber size variability and rimmed vacuole (black arrowhead), inset showing electron microscopy image of a rimmed vacuole with inclusions. 


\section{Section 2}

On our examination, there was right-sided scapular winging (figure, A), mild atrophy of shoulder girdle muscles, and a protruding abdomen (figure, B). In addition, there was substantial proximal > distal muscle weakness (deltoid: $3 / 5$; iliopsoas: $3+/ 5$; biceps, triceps, wrist flexor, finger extensor, quadriceps, and ankle dorsiflexion: ranged 4 to $4+/ 5$ on Medical Research Council scale). Grip strength was reduced (16 kg-force on right and $17 \mathrm{~kg}$-force left, normal range 28-59 $\mathrm{kg}$-force). Cranial nerves, reflexes, and sensory modalities were intact. There were no cerebellar signs. The patient had a waddling gait.

Weakness in the presence of multiple sclerotic bone lesions can raise suspicion for paraproteinemias, such as multiple myeloma and POEMS (polyneuropathy, organomegaly, endocrinopathy, monoclonal protein, and skin changes) syndrome, or a metastatic bone disorder. ${ }^{1,2}$ However, there was no firm evidence in support of these etiologies based on the initial workup. Subsequent biopsy of the left radial lesion revealed Paget disease of bone (PDB).

Considering the patient's proximal weakness, the differential is broad, encompassing myopathic and nonmyopathic etiologies. The inflammatory myopathies, dermatomyositis (DM) and polymyositis, should be highly considered given the proximal distribution of weakness, although normal muscle enzymes and negative autoantibodies make these diagnoses less likely. Moreover, he did not have any skin lesions typical for DM. Inclusion body myositis (IBM) should similarly be considered; however, quadriceps greater than hip flexors weakness and early involvement of distal muscles, for example, finger flexors and ankle dorsiflexors, would be expected. Genetic myopathies, such as limb-girdle muscular dystrophy and facioscapulohumeral muscular dystrophy, are enticing possibilities given shoulder girdle muscle weakness and scapular winging. However, lack of facial involvement and early leg involvement would be atypical for the latter and both typically present earlier in life. The origin of the weakness could also be nonmyopathic. Lambert-Eaton myasthenic syndrome may present with proximal weakness but the patient lacked fatigability or autonomic symptoms. Painless progressive weakness may raise concern for possible motor neuron disease but there were no upper or lower motor neuron signs. As discussed earlier, intact reflexes and absent sensory symptoms made CIDP unlikely. However, none of these conditions would explain the concurrent PDB.

To evaluate the etiology of the patient's weakness, an EMG was performed. His EMG revealed shorter amplitude and mildly polyphasic motor unit action potentials in deltoid and early recruitment in deltoid, biceps, iliopsoas, and vastus lateralis. There was no spontaneous activity or firm electrodiagnostic findings suggestive of muscle membrane irritability, which is commonly present in inflammatory myopathies.

These findings essentially suggested a myopathic picture and a biopsy of the patient's right quadriceps was performed. This demonstrated variability in myofiber size and increased internalized nuclei. Few rimmed vacuoles were also noted. Electron microscopy (EM) showed inclusions in these vacuoles (figure, $\mathrm{E}$ ).

\section{Question for consideration:}

1. What clinical disease spectrum would be consistent with the patient's clinical presentation?

GO TO SECTION 3 


\section{Section 3}

Rimmed vacuoles are a nonspecific finding in many myopathies, including sporadic IBM (sIBM) and myofibrillar myopathy (MFM). As noted previously, the patient's pattern of muscle involvement was not typical for sIBM. There was no amorphous or granular material on muscle histology and EM did not show myofibrillar degeneration to support MFM. Interestingly, rimmed vacuoles can also be found in a rare inherited spectrum of disorders known as inclusion body myopathy associated with Paget disease and frontotemporal dementia (IBMPFD). Knowing our patient was recently diagnosed with PDB, there was thus high clinical suspicion for this disorder. ${ }^{3-5}$

IBMPFD is a unique clinical syndrome with heterogeneous clinical presentation. ${ }^{3}$ Myopathy is found in $80 \%-90 \%$ of patients and is an isolated finding in $30 \%$ of patients. Although weakness is commonly proximal, distal muscle groups may be involved. Serum CK is typically normal or slightly elevated and EMG is myopathic, although occasional neurogenic features have been reported. Muscle biopsy often shows nonspecific changes including atrophy, variation in muscle fiber size, rimmed vacuoles, and inclusions with valosin-containing protein (VCP), ubiquitin, or TDP-43 reactivity.

About $50 \%$ of patients develop PDB, often a decade earlier than the typical presentation, and nearly $30 \%$ of patients with IBMPFD will develop frontotemporal dementia (FTD), usually the behavioral variant. The latter typically appears late in the disease course; therefore, patients should receive baseline neuropsychological testing. In our patient, neurocognitive testing revealed nonamnestic mild cognitive impairment. The pattern of deficits suggested frontal and parietal lobe involvement with mild impairment of executive functioning.

The complete triad associated with IBMPFD manifests in only $12 \%$ of individuals and additional associated features have also been reported. These include hepatic steatosis, cataracts, dilated cardiomyopathy, sphincter disturbances, sensorimotor axonal neuropathy, and cerebellar signs. ${ }^{4}$

\section{Question for consideration:}

1. How would you confirm the diagnosis?

GO TO SECTION 4 


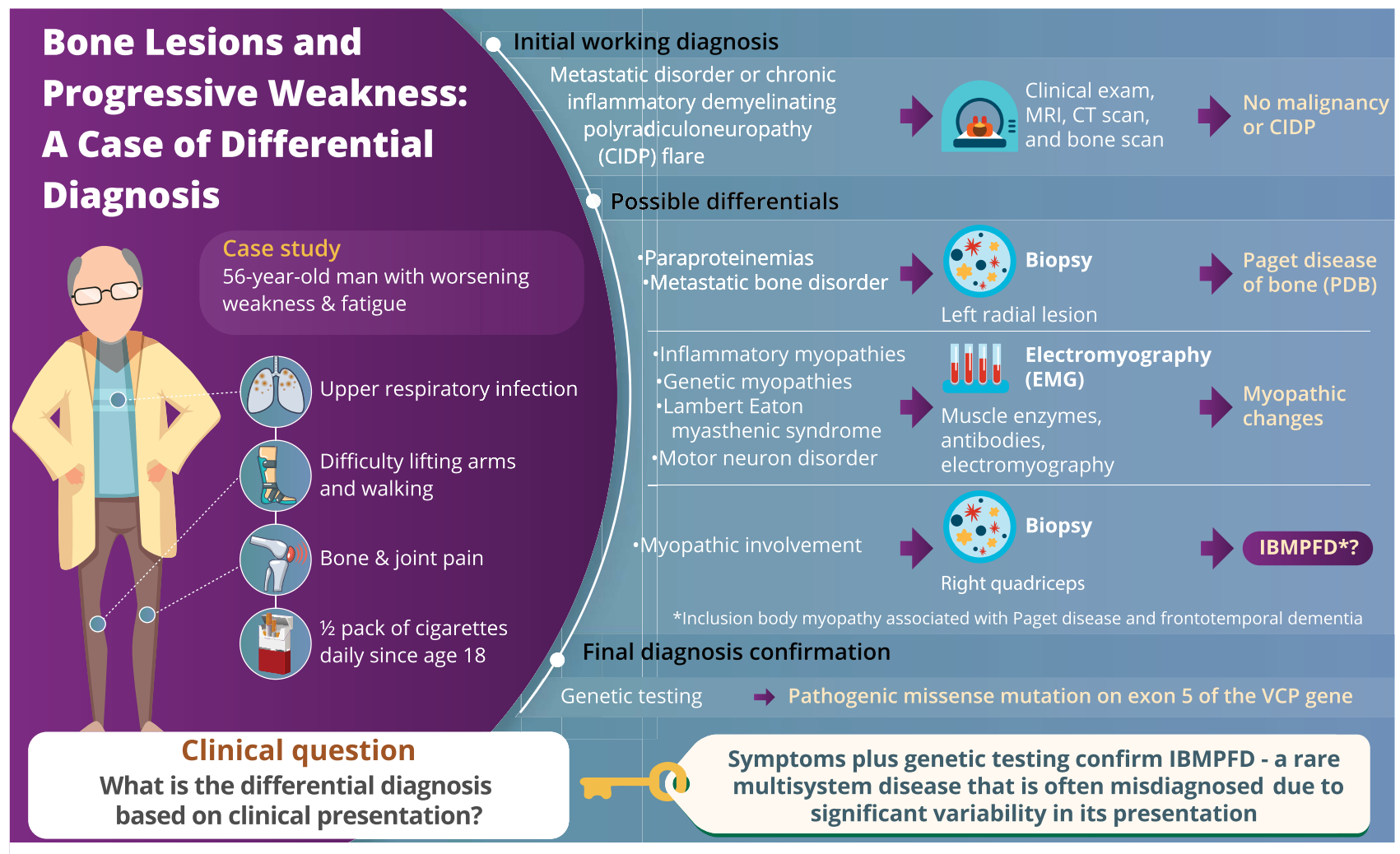

doi:10.1212/WNL.0000000000008535

Copyright @ 2019 American Academy of Neurology

Neurology"

\section{Section 4}

IBMPFD is an autosomal dominant disorder with variable penetrance secondary to $V C P$ gene mutation located at 9 p13.3. ${ }^{3}$ Genetic testing is essential to confirm the diagnosis. Our patient had a pathogenic missense mutation on exon 5 of the $V C P$ gene representing a heterozygous $\mathrm{G}>\mathrm{A}$ nucleotide change that results in substitution of arginine for histidine, which confirmed his diagnosis.

VCP is involved in DNA repair, apoptosis, cell cycle control, and protein degradation. About 45 different mutations have been described in IBMPFD. ${ }^{5}$ These mutations may disrupt VCP's normal roles in protein homeostasis, resulting in abnormal protein aggregation seen pathologically in IBMPFD. ${ }^{6}$

Recently, mutations in non-VCP proteins (SQSTM1, HNRPNA2B1, and HNRNPA1) have been associated with IBMPFD. As case descriptions of IBMPFD expand beyond the classical triad and other genes are implicated, multisystem proteinopathy has been proposed as a more appropriate classification. ${ }^{7}$ This terminology emphasizes the multiple systems and pathology shared among these disorders while allowing for heterogeneity in genetic and phenotypical presentation.

\section{Discussion}

IBMPFD is a rare multisystem disease that is often misdiagnosed due to substantial variability in its presentation. No treatments exist to modify or prevent its progression. Physical and occupational therapy and assistive devices can promote functionality. Bisphosphonates may improve bone pain in patients with $\mathrm{PDB}$, despite no convincing evidence that treatment alters disease course. ${ }^{8}$ Selective serotonin reuptake inhibitors may be beneficial for behavioral symptom management in those patients with FTD. ${ }^{9}$ In later stages, patients may present with respiratory or cardiac failure; some patients may eventually require assisted ventilation. EKG, echocardiogram, and regular pulmonary function tests are recommended.

This case represents the diagnostic challenges associated with IBMPFD. To make a unifying diagnosis for this heterogeneous multisystem disorder may not be straightforward and requires high clinical suspicion. This should be in the differential when evaluating patients with myopathy and concurrent bone disease. Early recognition may help to better manage associated complications and improve quality of life.

\section{Study funding}

No targeted funding reported.

\section{Disclosure}

T. Torabi and A. Huttner report no disclosures relevant to the manuscript. R. Nowak reports serving as an advisor/ consultant for Alexion, Ra Pharma, Momenta, Roivant, Grifols, and Shire and receiving grant/research support from the NIH, Myasthenia Gravis Foundation of America, Muscular Dystrophy Association, Alexion, Ra Pharma, Grifols, and Genentech. None of the above disclosures is relevant to the manuscript. B. Roy reports no disclosures relevant to the manuscript. Go to Neurology.org/N for full disclosures. 
Appendix Authors

\begin{tabular}{llll}
\hline Name & Location & Role & Contribution \\
\hline $\begin{array}{l}\text { Tara } \\
\text { Torabi, MSc }\end{array}$ & $\begin{array}{l}\text { Yale } \\
\text { School of } \\
\text { Medicine }\end{array}$ & Author & $\begin{array}{l}\text { Study concept and design, } \\
\text { analysis and interpretation of } \\
\text { data, revising of manuscript }\end{array}$ \\
\hline $\begin{array}{l}\text { Anita } \\
\text { Huttner, }\end{array}$ & Yale & School of \\
MD & Medicine & Author & $\begin{array}{l}\text { Analysis and interpretation of } \\
\text { data, revising of manuscript }\end{array}$ \\
\hline $\begin{array}{l}\text { Richard J. } \\
\text { Nowak, } \\
\text { MD, MS }\end{array}$ & $\begin{array}{l}\text { Yale } \\
\text { School of }\end{array}$ & Author & $\begin{array}{l}\text { Analysis and interpretation of } \\
\text { data, revising of manuscript }\end{array}$ \\
\hline $\begin{array}{l}\text { Bhaskar } \\
\text { Roy, MD }\end{array}$ & $\begin{array}{l}\text { Yale } \\
\text { School of } \\
\text { Medicine }\end{array}$ & Author & $\begin{array}{l}\text { Study concept and design, } \\
\text { analysis and interpretation of } \\
\text { data, revising of manuscript }\end{array}$ \\
\hline
\end{tabular}

\section{References}

1. Batsis JA, McDonald FS. 76-year-old man with back pain and progressive leg weakness. Mayo Clin Proc 2005;80:259-262.

2. Waning DL, Guise TA. Molecular mechanisms of bone metastasis and associated muscle weakness. Clin Cancer Res 2014;20:3071-3077.

3. Kimonis VE, Mehta SG, Fulchiero EC, et al. Clinical studies in familial VCP myopathy associated with Paget disease of bone and frontotemporal dementia. Am J Med Genet A 2008;146A:745-757.

4. Weihl CC, Pestronk A, Kimonis VE. Valosin-containing protein disease: inclusion body myopathy with Paget's disease of the bone and fronto-temporal dementia. Neuromuscul Disord 2009;19:308-315.

5. Al-Obeidi E, Al-Tahan S, Surampalli A, et al. Genotype-phenotype study in patients with valosin-containing protein mutations associated with multisystem proteinopathy. Clin Genet 2018;93:119-125.

6. Watts GD, Wymer J, Kovach MJ, et al. Inclusion body myopathy associated with Paget disease of bone and frontotemporal dementia is caused by mutant valosin-containing protein. Nat Genet 2004;36:377-381.

7. Taylor JP. Multisystem proteinopathy: intersecting genetics in muscle, bone, and brain degeneration. Neurology 2015;85:658-660.

8. Wat WZ. Current perspectives on bisphosphonate treatment in Paget's disease of bone. Ther Clin Risk Manag 2014;10:977-983.

9. Young JJ, Lavakumar M, Tampi D, Balachandran S, Tampi RR. Frontotemporal dementia: latest evidence and clinical implications. Ther Adv Psychopharmacol 2018;8:33-48.

\section{AAN Online Learning Center}

Browse a variety of online CME, self-assessment, and other learning activities to suit your wide-ranging interests and learning styles. Visit Learning.AAN.com today to access the Online Learning Center, your exclusive member-only hub for AAN continuing medical education.

\section{Subspecialty Alerts by E-mail!}

Customize your online journal experience by signing up for e-mail alerts related to your subspecialty or area of interest. Access this free service by clicking on the "My Alerts" link on the home page. An extensive list of subspecialties, methods, and study design choices will be available for you to choose from-allowing you priority alerts to cutting-edge research in your field!

\section{Neurology.org/N Offers Important Information to Patients and Their Families}

The Neurology ${ }^{\circledR}$ Patient Page provides:

- A critical review of ground-breaking discoveries in neurologic research that are written especially for patients and their families

- Up-to-date patient information about many neurologic diseases

- Links to additional information resources for neurologic patients

All Neurology Patient Page articles can be easily downloaded and printed, and may be reproduced to distribute for educational purposes. Click on the 'Patients' link on the home page (Neurology.org/ $\mathrm{N}$ ) for a complete index of Patient Pages. 


\section{Neurology}

\section{Clinical Reasoning: Progressive proximal weakness in a 56-year-old man with bone pain}

Tara Torabi, Anita Huttner, Richard J. Nowak, et al. Neurology 2019;93;939-944

DOI 10.1212/WNL.0000000000008535

This information is current as of November 18, 2019

\section{Updated Information \&} Services

References

Subspecialty Collections

Permissions \& Licensing

Reprints including high resolution figures, can be found at: http://n.neurology.org/content/93/21/939.full

This article cites 9 articles, 2 of which you can access for free at: http://n.neurology.org/content/93/21/939.full\#ref-list-1

This article, along with others on similar topics, appears in the following collection(s):

All Genetics

http://n.neurology.org/cgi/collection/all_genetics

All Neuromuscular Disease

http://n.neurology.org/cgi/collection/all_neuromuscular_disease Frontotemporal dementia

http://n.neurology.org/cgi/collection/frontotemporal_dementia

Information about reproducing this article in parts (figures,tables) or in its entirety can be found online at:

http://www.neurology.org/about/about_the_journal\#permissions

Information about ordering reprints can be found online:

http://n.neurology.org/subscribers/advertise

Neurology ${ }^{\circledR}$ is the official journal of the American Academy of Neurology. Published continuously since 1951, it is now a weekly with 48 issues per year. Copyright () 2019 American Academy of Neurology. All rights reserved. Print ISSN: 0028-3878. Online ISSN: 1526-632X.

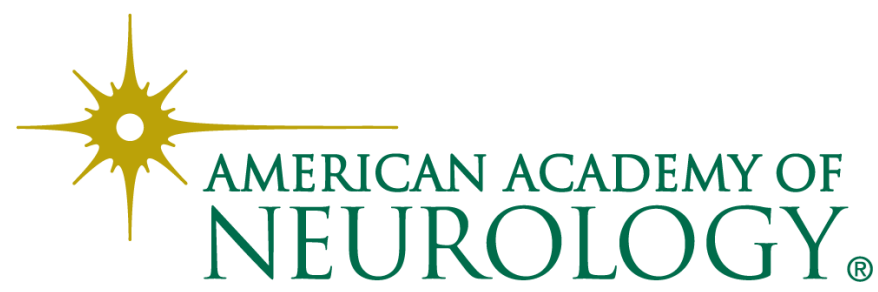

